\title{
BASYTAMA CONCEPTS OF SHARIA FINANCIAL LITERATURE ACCELERATION IN PREPARING EXCELLENT HUMAN RESOURCES BASED ON VILLAGE COMMUNITIES
}

\author{
Daffa Redika Fauzi ${ }^{1}$, Fatimah Adzakiyah Shalihah², Prisilia Hadi ${ }^{3}$, Dian Purnomo Jati ${ }^{4}$ \\ 1,2,3,4 Faculty of Economics and Business, Jenderal Soedirman University, Purwokerto \\ Email: daffa.rfauzi.drf@gmail.com
}

\begin{abstract}
Indonesia's Islamic finance sector (Halal Finance) is experiencing rapid growth. In a pandemic situation, Islamic banking grows consistently. It recorded that in 2020 , Islamic banking grew by 9.22\%. Based on the Islamic Finance Development Index issued by the Islamic Corporation for the Development of the Private Sector (ICD), Indonesia's Islamic finance industry managed to climb to rank two after previously occupying the 4th position. The productive age of the population also has considerable potential to increase the number of Islamic bank customers in Indonesia. This is also becoming more potential because based on data from the Central Statistics Agency in 2019 Indonesia has 83,820 villages. However, on the other hand, based on a survey from the Financial Services Authority (OJK) in 2019, the Islamic financial literacy index of the Indonesian people only reached $8.93 \%$. Based on the potential and existing problems, this study aims to develop a concept of public interest in using Islamic bank products through the Bank Syariah Kita Bersama (Basytama) program which is part of a community empowerment strategy and builds superior human resources through the development of community-based Islamic financial ecosystem institutional aspects. village. This research is based on descriptive qualitative analysis. This is supported by the use of primary and secondary data, in primary data collection we use distributing questionnaires to people and conducting interviews by telephone or virtual conference based on in-depth interviews. contact. In addition, to help support research to obtain more comprehensive and extensive data, we also use secondary data through library research, using various trusted and credible reference sources. The conceptual model of Basytama focuses on aspects of Islamic banking, empowerment, and education in rural communities. We base this concept on Basytama programs such as collecting and distributing funds, collaborating with stakeholders at the village level, opening assistance programs, and researching village potentials through the Basytama Institute so that it is hoped that an increase in the competence and standard of living of the community will be achieved accompanied by an increase in the quality of life. Islamic financial literacy at the village level.
\end{abstract}

Keywords: Islamic Finance Industry, Islamic Financial Literacy Index, Building Superior Human Resources, Bank Syariah Kita Bersama (Basytama) 


\section{Introduction}

\section{Background}

Growth in implementing the Islamic monetary system increased rapidly in four decades in various countries such as Malaysia in the mid-1940s, in Pakistan in the late 1950s, and Egypt through the Mit Ghamr Bank and Nasser Social Bank. The growth of the Islamic finance sector was growing in the 1970s. According to (Siddiqi 1996), this time span is the time when Islamic banking in the world experienced a revival. The rise of the world of Islamic banking in various Islamic countries certainly affects the development of the Islamic finance sector in Indonesia.

Indonesia with the second largest Muslim population in the world with a Muslim population of $276,361,782$ in 2021 , amounting to $87.20 \%$ of the total population, and $12.70 \%$ of the total world population, feels various influences on the growth of the Islamic finance sector in Indonesia. various Islamic countries in the world. Starting in 1991 Bank Muamalat Indonesia was established and officially operated in 1992. However, the large development of Islamic banking in Indonesia only occurred after 1998 (Rae 2008).

Indonesia continues to show development and progress in the Islamic banking sector from year to year. The Global Islamic Economic Report (2020) reports that the value of Islamic financial assets is estimated to increase by 13.9 percent for 2019. The nominal value of $\$ 2.52$ trillion increases to $\$ 3.88$ trillion. In 2021 , Islamic finance will also grow positively (Dinar Standard 2020). In May 2021, Islamic banking assets grew 15 percent. The data shows that the pandemic has not dampened the pace of Islamic banking to continue to grow.

Seeing significant and consistent progress and promising great potential. Researchers sparked the idea of a sharia bank product, Bank Syariah Kita Bersama (Basytama) by empowering rural communities which are expected to provide benefits for the wider community to improve various aspects that are the way to achieve prosperity.

\section{Problem Formulation}

Based on the background of the research to be conducted, the following problem formulations can be drawn:

1. How is the public interest in using Islamic bank products through the Bank Syariah Kita Bersama (Basytama) program which is part of the community empowerment strategy through the development of institutional aspects of the Islamic financial ecosystem community based village community?

2. Can the Bank Syariah Kita Bersama (Basytama) program help achieve an increase in people's living standards?

3. Is the Bank Syariah Kita Bersama (Basytama's program) can improve Islamic financial literacy at the village level?

\section{Objectives}

Based on the formulation of the problem, we can find out the research objectives, namely:

1. To find out the public's interest in using Islamic bank products through the Kita Bersama Syariah Bank (Basytama) program which is part of a community empowerment strategy through the development of community-based Islamic financial ecosystem institutional aspects village.

2. To find out that the Bank Syariah Kita Bersama (Basytama) program can help achieve an increase in people's living standards.

3. To find out that the Bank Syariah Kita Bersama (Basytama) program can increase 
Islamic financial literacy at the village level.

\section{Benefits}

From the background and objectives of the research above, the benefits of this research can be found, namely:

1. Providing information about public interest in the Islamic Bank program which is part of the community empowerment strategy through the development of institutional aspects of the Islamic financial ecosystem based on rural communities.

2. Providing information about programs with aspects of sharia banking, empowerment, and education can be implemented so as to support the development of literacy and welfare of rural communities.

3. The results of the study can be used as a reference for developing Islamic banking products based on rural communities.

\section{Literature Review}

\section{Theory}

1. Sharia Economic Literacy Index

The Islamic Economic Literacy Index is an individual's knowledge of Islamic sharia values in managing and using their assets to achieve prosperity in a balanced manner (Bank Indonesia 2021). The 2019 Islamic economic literacy index is 16.3 percent while the national sharia financial inclusion index is 9.1 percent. Meanwhile, the 2020 Bank Indonesia survey showed the national sharia economic and social finance literacy index of 16.2 percent.

2. Islamic Finance Industry

Indonesia's Islamic finance industry is growing rapidly and is currently ranked second after Malaysia. According to IDX until February 2021, Indonesia's total Islamic financial assets reached IDR 1,836 trillion. This figure increased from the position in December 2020, which amounted to Rpl,803 trillion (an increase of $10.9 \%$, compared to conventional banks which only grew 7.7\%) (Hartomo 2021).

Table 1 Table of Number of Banks in Indonesia

\begin{tabular}{l|lll} 
BANK TYPE & DECEMBER 2019 & DECEMBER 2020 & JULY 2021 \\
\hline CONVENTIONAL BANK & 110 & 109 & 107 \\
\begin{tabular}{l} 
ISLAMIC BANK \\
\multicolumn{1}{c}{ Source: Financial Services Authority (OJK) July 2021. }
\end{tabular} & 12
\end{tabular}

Table 2 Table of Total Banking Assets in Indonesia

BANK TYPE

\section{CONVENTIONAL BANK}

ISLAMIC BANK
TOTAL ASSETS (IN BILLION RUPIAH)

$9,411,164$

Source: Financial Services Authority (OJK) June 2021.

Indonesia is ranked 5th in the top 5 countries by asset value, with USD 3 billion (Nurrahman 2019). Sharia economic sectors that have the potential to be developed in Indonesia include the sharia banking industry, non-bank financial institutions, capital markets, Islamic hospitals, hotels, tourism, halal culinary, and fashion. According to the President Director of PT Bank Syariah Indonesia Tbk. (BSI) Hery Gunardi, as of November 
2020, of the 180 million Muslim population in Indonesia, around 30.27 million people are registered as customers of Islamic banks. However, during this pandemic, the digital Islamic banking sector has increased. This is reflected in data as of June 2021, the number of BSI Mobile users reached 2.2 million users and BSI mobile transactions grew by $113 \%$ on an annual basis (CNN Indonesia 2021).

3. Islamic Bank

a. Definition of Islamic Bank

According to law No. 21 of 2008 concerning Islamic banking, it is stated that Islamic banking is everything related to Islamic banks and sharia business units, including institutions, including business activities, and procedures and processes in carrying out their business activities. In conclusion, Islamic banks are financial institutions in charge of collecting funds from the public, channeling funds to the public, and providing financial services to the public by using the rules that apply in the teachings of Islam.

The number of Islamic banks that are not as many as conventional banks indicates that the Indonesian people are still not familiar with Islamic banks. This is what causes public knowledge about Islamic banking is still limited. Even if it is seen from the following data, there are more conventional bank branch offices than bank service offices and sharia business units, so people prefer to use conventional bank products because of easy and close access.

Table 3 Number of Branch Offices Based on Bank Locations in Indonesia

BANK TYPE CONVENTIONAL BANK ISLAMIC BANK
DECEMBER 2020

3,616

2,964
JUNE 2021

3,615

3,258

Source: Financial Services Authority (OJK) June 2021.

b. Sharia Bank Products

According to law No. 21 of 2008 concerning about Islamic banking, definition of Islamic banking is everything related to Islamic banks and sharia business units, including institutions, including business activities, and procedures and processes in carrying out their business activities (Otoritas Jasa Keuangan 2008). The business activities of Islamic Commercial Banks include:

1) Collect funds in the form of deposits in the form of Current Accounts, Savings Accounts, or other forms that equated with it based on the wadi'ah contract or other contracts that do not conflict with the sharia principles;

2) Collect funds in the form of investment in the form of Deposits, Savings, or other forms that equated with it based on the Akad Mudharabah or other contracts that are not contradictory with sharia principles;

3) Distribute profit-sharing Financing based on the Akad Mudharabah, Musyarakah contract, or other contracts that does not conflict with sharia principles;

4) Channeling financing based on Akad Murabahah, Salam contract, Istishna contract, or other contract which does not conflict with Sharia Principles;

5) Channeling financing based on a Qardh contract or other contracts that do not conflict with the sharia principles;

6) Distribute movable goods leasing financin or immovable to the customer based on the Akad ljarah and/or lease purchase in the form of ljarah Muntahiyah Bittamlik or other contracts that are not contrary to sharia principles; 
7) Take over debt based on the akad Hawalah or other contracts that do not conflict with sharia principles;

8) Doing business with debit card and/or card financing based on sharia principles;

9) Buy, sell or guarantee at your own risk third party securities issued on the basis of real transactions based on Sharia Principles, between others, such as ijarah contract, musyarakah, mudharabah, murabahah, kafalah, or hawalah;

10) Buy securities based on sharia principles issued by the government and/or Bank Indonesia;

11) Receive payment from bills on securities and perform calculations with third parties or between third parties based on sharia principles;

12) Doing custody for the benefit of other parties based on a contract based on the principls sharia;

13) Provide a place to store goods and securities based on sharia principles;

14) Move money, either for its own sake as well as for the benefit of the Customer based on sharia principles;

15) Perform functions as a Trustee based on Wakalah contract;

16) Provide letter of credit or bank guarantee facilities based on Sharia Principles;

17) Carry out other activities commonly carried out in the field of banking and in the social sector as long as not contrary to Sharia Principles and in accordance with the provisions of the legislation.

According to Kasmir (2010) the following are the types of Islamic bank products:

1) Funding Products

a) The principle of buying and selling, by transferring ownership of goods.

b) The principle of lease, namely the transfer of usufructuary rights to goods or services without being followed by a transfer of ownership of the goods being leased.

c) The principle of profit sharing, namely working together to increase the assets owned.

2) Fundraising Products

a) The principle of Wadiah (savings) is wadiah yad dhamanah, the party entrusted with is responsible for the integrity of the deposited property so that he may take advantage of the deposited property. Then there is the wadiah yad amanah, the entrusted property cannot be used by the entrusted person.

b) Mudharabah Principle.

c) Depositors or depositors of funds act as owners of capital while banks act as managers. Funds deposited by the bank are used to carry out financing.

3) Banking Service Products

Islamic banks can provide services to customers by getting compensation in the form of rent or profit.

4. Intersest

Intersest is defined as an impulse that causes a person to do what he wants to do voluntarily, and in a state of free choice (Sukanto 1985). When someone judges that something will be useful, it will become intersested, then it will bring satisfaction. When satisfaction decreases, interest will also decrease. So that intersest is not permanent, but interest is temporary or can change. There are several stages of intersest, including:

a. Clear information before becoming a customer

b. Careful consideration before becoming a customer 
c. The decision to become a line age (Sukanto 1985).

Public intersest in Islamic banks is also an important factor that needs to be owned so that people can determine their decision to choose what bank services they want to use.

5. Customer

According to Kasmir (2010) that the customer is who buys, uses the products or services provided by the bank. Based on the Law of the Republic of Indonesia Number 21 of 2008 concerning Islamic banking, what is meant by the customer is the party who uses the services and services of a sharia bank and or sharia business unit.

Previous Studies and Research

Dayyan et al (2017) The interest of the Muslim community to become a customer of a sharia bank (Case Study in Pondok Kemuning Village) is influenced by the knowledge, approaches and product offerings carried out by Islamic banks as well as the income of the community. There are several factors that influence people's interest in saving at Islamic banks, including: knowledge, services, and the location of Islamic banks that are used as a place to save (Indi 2019). While According to Izzati (2018), it is stated that profit sharing, service, and accessibility factors (location and distance) have a significant effect on student interest in saving at Islamic banks.

Utilization of Sharia Microfinance Institutions (LKMS) will directly increase the income and income of rural communities by increasing capital and strategic business places (Oktafia, R.; Ulfatul 2012). The factors that influence the development of Islamic banking in Indonesia are: efficiency; public awareness, education and knowledge about Islamic banking and bank interest; regulation; fatwa prohibiting interest and usury; integration of Islamic Financial Institutions (LKS); and competitiveness of Islamic banking in Indonesia, as well as the potential Muslim population in Indonesia (Amdar 2016)According to the aspect of benefit received by the community affects the acceptance of Islamic financial institutions.

\section{Research Methods}

\section{Methods}

The writing method in this work uses a descriptive method using a qualitative approach. This paper is structured to answer the formulation of the problem by describing the problem based on the theoretical basis to be studied. Studying the problem to create a solution in this paper is done by reading the literature that is following the focus of the problem at hand. In addition to supporting writing, the author also conducted a literature study which was then harmonized with existing ideas and problems.

\section{Data Type}

Writing in this scientific paper uses primary data and secondary data. Qualitative data in the form of analysis of problems related to superior HR development strategies oriented to increasing Islamic financial literacy in rural communities. Our primary data search used questionnaires and also semi-structured interviews with representatives of several elements of society evenly, so that more open data would be obtained. This type of semi-structured interview is included in the in-depth interview category, which in its implementation is more free than structured interviews (Gunawan 2013).

\section{Data Source}

This scientific work uses data from distributing questionnaires to various parties and groups with an age range of 15-50 years with the aim of getting opinions from each object briefly and using in-depth interviews with several community groups and also academics with the aim of 
getting in-depth views. On the other hand, we also conducted a literature study with the aim of adding information and data from various credible parties.

\section{Data Analysis Technique}

The data collected is then used as material in analysis. The analysis was carried out qualitatively so that conclusions can be drawn based on the discussion of each of the problems raised. The steps in analyzing the data are as follows:

1. Data Collection (Data Collection)

Data and information were obtained from the informants using interviews, questionnaires, and documented literature studies. Then, it is combined into an observation note in which there are two aspects, namely a description note which is a natural record that contains what is heard, experienced, recorded, seen, felt without any response from the researcher to the phenomena that occur. The second is reflection notes, namely notes that contain the impressions of messages, comments, and interpretations of researchers about the phenomena they face, these notes are obtained from the results of interviews with various informants.

2. Data Reduction (Data Reduction)

Data reduction is a process of selecting, focusing on the steps of simplification, abstraction, and transformation of rough data that emerges from written records in the field.

3. Data Display (Data Display)

The presentation of the data is intended to facilitate the author in terms of seeing the description of the observations and the process of making conclusions because the observations are still in the form of independent data.

4. Conclusion Drawing

The final step in qualitative data analysis is drawing conclusions. Drawing conclusions is an attempt to find or understand the meaning of regularity, patterns, clarity, causal paths or, propositions (Bungin 2001).

Before we formulate the conclusion after showing the data we conduct a swot analysis on the Basytama concept. Analysis Strengths - Weaknesses - Opportunities - Threats (SWOT) analysis is an analytical tool useful for managers in developing strategies such as power - opportunities (SO), weakness - opportunities (WO), strength - the threat (ST), and weaknesses - threat (WT) (David 2011)The implementation of the SO strategy will take advantage of the strengths of the company's internal side to later take advantage of external opportunities, the WO strategy aims to improve internally by taking advantage of external opportunities, the ST strategy will use the strengths of the company's internal body and reduce or avoid external threats, while the ST strategy will use the strengths of the company's internal body and reduce or avoid external threats. WT is a defensive technique carried out by companies in order to reduce internal weaknesses and avoid external threats.

\section{Writing Stage}

The stages of writing are used as the main framework in writing essays. This stage is the steps in finding problems, identifying problems, finding solutions, and expressing them in a written work in detail. There are 6 stages of writing scientific papers, namely as follows:

1. Assessing problems related to unbanked communities, the Islamic financial literacy index which is still quite low, and analyzing the potential of villages in Indonesia.

2. Identify related problems according to the topics studied.

3. Formulate the problem according to the focus of the problem being studied and analyzed.

4. Searching for data through distributing questionnaires, interviews with various elements of society, and literature studies. 
5. Collecting data to support the sharpness of the analysis of existing problems.

6. Analyze and discuss the concept of the right solution, to improve the Islamic financial literacy index and prepare superior human resources who are educated in sharia economics based on rural environments, then draw conclusions based on the findings and concepts that have been formulated.

\section{Result and Discussions}

\section{The Conditions of Village Community's Interest to Sharia Banking Products}

In village as the main player in grounding the sharia economy, is expected to play a serious role. Based on the results of interviews with several informants, they need a sharia bank that is specific to the village scope. Where the socialization process is not only carried out by the bank, but also from the community itself so that it will foster a higher value trust, because it is proof of their trust and recommends it through the closest people. When interviewing several informants, they admitted that there were still many people in their villages who did not know about Islamic banking products and the urgency of Islamic finance in the midst of today's life. In addition, based on the informants we interviewed, especially village youth, it was deemed necessary to be the main key holder for the implementation of Islamic economic grounding in the village community, they are willing if a program is held to introduce Islamic finance and banking in the community while deepening the knowledge.

Another condition described by the informants is the lack of information about Islamic finance in the village, both Islamic financial institutions (LKS) and non-Islamic financial institutions (NonLKS), because there is no direct socialization and education like conventional banks which generally have good behavior, compared to current Islamic banking which does not yet exist and does not yet live in the midst of rural communities, so it is natural that they lack information about the world of finance and Islamic banking. This is also in line with the informants' acknowledgment that the distance of Islamic banks is still further than conventional banks and the desire of rural communities to save in simple, easy, and fast conditions. Based on these things, it can be seen that it is necessary for Islamic banks to be present in the village community, but their presence is not only an ordinary Islamic banking, but is able to contribute and play a role in village development through the community. In addition, based on the results of our questionnaire with 29 respondents, our research subjects were $89.7 \%$ were students and $10.3 \%$ were the general public.

\section{Researched Factor}

The application of sharia economics in the management of family or village finances

Get to know the concept of Islamic finance

Understand the difference between sharia and conventional financial management
Table 4. Interview Result Already Not yet

Maybe ever

$20,7 \%$ respondent

$27,6 \%$ respondent

$51,7 \%$ respondent

$55,2 \%$ respondent

$17,2 \%$ respondent

$27,6 \%$ respondent $65,5 \%$ respondent $17,2 \%$ respondent

$17,2 \%$ respondent 


\begin{tabular}{|c|c|c|c|c|}
\hline $\begin{array}{ll}\text { Village youth } & \text { know } \\
\text { information } & \text { about } \\
\text { sharia finance } & \end{array}$ & $0 \%$ respo & $24,1 \%$ & ondent & $75,9 \%$ responde \\
\hline $\begin{array}{l}\text { The level of customer } \\
\text { trust in Islamic financial } \\
\text { products }\end{array}$ & $\begin{array}{c}37,9 \% \\
\text { (Strongly } \\
\text { believes) }\end{array}$ & $\begin{array}{c}51,7 \% \\
\text { (Just believes) }\end{array}$ & $\begin{array}{c}6,9 \% \\
\text { (Neutral) }\end{array}$ & $\begin{array}{c}3,4 \% \\
\text { (Never) }\end{array}$ \\
\hline
\end{tabular}

\section{Strategy For Increasing Interest in Sharia Banking Products and Sharia Financial Literacy}

Bank Syariah Kita Bersama (Basytama) is an accelerative concept in alleviating the problems of low Islamic financial literacy in Indonesia and developing villages to prepare superior human resources who can later become pioneers of the sharia economy in their home environment. Basically, Basytama has four main functions in improving the financial literacy of sharia, introduce Islamic banking, and set up a superior human resource:

1. The basic function Basytama is collecting funds in rural communities by basing the concept of sharia, so the contract-contract and financial activity in it in line with this concept. The opening of Islamic financial products in the village is carried out in stages which are adjusted to the level of Islamic financial literacy, interest, and potential based on the results of research analysis from the Basytama Institute. and Research Center.

2. The next function of Basytama is empowerment with the Basytama Pundak Desa program, the program is not necessarily carried out by Basytama itself. Instead, Basytama collaborates with various officials stakeholders organizations that do exist in the village such as youth, youth mosques, Islamic boarding schools, madrasas, and village. The goal is to be able to accommodate and revive community empowerment in grounding the sharia economy, in which they can carry out various kinds of cooperation such as internships at Basytama which are prioritized for local village communities, coaching clinics for youth mosques and Islamic boarding schools, especially in reporting financial records from sharia cooperatives. both owned by the mosque and owned by the Islamic boarding school.

3. The function of education and socialization at Basytama is carried out with the Basytama talk with neighborhood association program, in this program Basytama conducts socialization about programs at Basytama such as Basytama Pundak Desa, Basytama Institute and Research Center, and Islamic banking activities in Basytama as well as educating the public about sharia economics by utilizing RT activities such as meetings, social gathering, and sponsorship of activities that are sometimes carried out at the RT level. In addition, Basytama's HR actively participates in social activities in the RT/village during holidays, where this can be used by Basytama in building branding in the community, making it easier to capture and establish family relationships with the local community. On the other hand, Basytama can provide various kinds of educational facilities with the community such as smart behavior that is indeed in the community which will later be able to accommodate and contribute to solving community stigma regarding Islamic banking and Basytama's human resources can participate in various studies or sermons in the village on a regular basis. The goal is that education and socialization of sharia economics can be evenly distributed among various groups of people in the village.

4. The last function at Basytama is development and research, where this function is realized by the Basytama Institute and Research Center program. Efforts in realizing the 
creation of superior human resources by providing facilities for development and research, the Basytama program Institute This and Research Center has two main functions, in the Basytama Institute program, the community, especially those who have collaborated with Basytama such as Islamic boarding schools, mosque youth, and youth organizations, can be trained and receive simple material with the aim of being able to apply it to life in a practical and practical way. become agents of change in their respective environments, at least from their own families. The development program can be carried out by involving Basytama in the curriculum of Islamic boarding schools, facilitating the community, especially youth mosques/Islamic boarding schools in taking professional certifications such as becoming zakat amil in their environment by collaborating with associations in accordance with their fields, opening courses for local youth to be able to Studying at Basytama directly in turns, the aim is to foster interest and prepare them to become the nation's successors who will ground the sharia economy in Indonesia. The next main function is from the research center. Basytama continues to explore the potential of the village by optimizing its research team by utilizing the research team in digging up data on the village. On the other hand, the research center is also a medium for Basytama to provide assistance to the local community, by opening assistance it will certainly make it easier for Basytama to obtain data as well as prepare superior human resources who are trained in the field of research and science.

The four programs above become a coherent unit where each program has its own focus, but all of them are related and focus on developing superior human resources in the village based on improving Islamic financial literacy. In summary, the Basytama concept is described as follows. This program will certainly provide benefits to the village community, especially in the short and long term.

1. Short term benefits:

a. Increased public interest.

b. Improvement of public knowledge.

c. Village potentials and threats are well mapped.

d. The skills and experience of the village youth increased.

2. Long term benefits:

a. The formation of community leaders and youth who understand financial literacy and sharia economics in general.

b. Sustainable village education curriculum.

c. Sustainable village development.

d. Increasing the professionalism of the youth.

e. Professional development in the village.

f. Transformation of the education level of the population. 


\section{SWOT Analysis Basytama}

SWOT analysis on Basytama is formulated in a matrix with a combination of SO, WO, ST, and WT which is described in the matrix as follows:

Table 5 Basytama Matrix SWOT

\begin{tabular}{l|l|l|l} 
Components of & \multicolumn{2}{c}{ Strengths (S) } \\
\hline & $\begin{array}{l}\text { 1. There are no competitors from } \\
\text { Islamic banks in the village. }\end{array}$ & $\begin{array}{l}1 . \quad \text { It takes time to introduce } \\
\text { Islamic economics to the } \\
\text { public. }\end{array}$ \\
\hline & $\begin{array}{l}\text { 2. Basytama is located in the } \\
\text { middle/close to the villagers. }\end{array}$ & $\begin{array}{l}\text { 2. Infrastructure in the village } \\
\text { is limited. }\end{array}$ \\
\hline $\begin{array}{l}\text { 3. The products available comply } \\
\text { with sharia guidelines. }\end{array}$ & $\begin{array}{l}\text { 3. Basytama's human } \\
\text { resources are not many. }\end{array}$ \\
\hline $\begin{array}{l}\text { 4. The program is aimed at financial } \\
\text { inclusion, development rural } \\
\text { community, and sustainable research. }\end{array}$ & $\begin{array}{l}\text { 5. The costs required are not as } \\
\text { much as when setting up Islamic banks } \\
\text { in urban areas. }\end{array}$ & \\
\hline
\end{tabular}

Opportunity (O) SO Strategy $\quad$ wO Strategy

\begin{tabular}{|c|c|c|}
\hline $\begin{array}{l}\text { 1. Stakeholders who } \\
\text { have been established in } \\
\text { the village earlier. }\end{array}$ & $\begin{array}{l}\text { 1. Socializing Basytama to the } \\
\text { community with existing } \\
\text { programs either directly or } \\
\text { through intermediaries (S1, S2, } \\
\text { S3, S4, O1, O2). }\end{array}$ & $\begin{array}{l}\text { 1. Build cooperation with } \\
\text { stakeholders and be active in } \\
\text { socializing the sharia } \\
\text { economy (W1, W2, W3, O1, } \\
\text { O2). }\end{array}$ \\
\hline $\begin{array}{l}\text { 2. Village community } \\
\text { growth. }\end{array}$ & $\begin{array}{l}2 . \quad \text { Choose access and } \\
\text { strategic locations in the village } \\
(\mathrm{S} 2, \mathrm{~S} 5, \mathrm{O}, \mathrm{O} 4) \text {. }\end{array}$ & $\begin{array}{l}2 . \quad \text { Utilizing the natural } \\
\text { potential of the village in } \\
\text { saving the company's } \\
\text { operational costs with a } \\
\text { simple power plant (W2, O4). }\end{array}$ \\
\hline $\begin{array}{l}\text { 3. Equitable distribution } \\
\text { of infrastructure by } \\
\text { local/central } \\
\text { governments. }\end{array}$ & & \\
\hline
\end{tabular}




\section{The natural potential of the village in energy breakthroughs.}

Threats ( $\mathrm{T})$

ST Strategy

WT Strategy

\begin{tabular}{l|l|l|l}
\hline $\begin{array}{l}\text { 1. Did not get land to } \\
\text { set up an office. }\end{array}$ & $\begin{array}{l}\text { Renting buildings in the } \\
\text { village or establishing } \\
\text { partnerships with outside } \\
\text { investors in providing } \\
\text { workplace facilities }(\mathrm{S} 2, \mathrm{~T}) \text { ). }\end{array}$ & $\begin{array}{l}\text { carrying equipment and devices } \\
\text { when carrying out Islamic } \\
\text { banking activities (W2, W3, T1, } \\
\text { T2). }\end{array}$ \\
\hline $\begin{array}{l}\text { 2. Not well received } \\
\text { by the local community. }\end{array}$ & $\begin{array}{l}2 . \quad \text { Provide education and } \\
\text { support village community } \\
\text { activities by playing an active } \\
\text { role in it (S3, S4, T2). }\end{array}$ & $\begin{array}{l}2 . \quad \text { Providing various kinds of } \\
\text { facilities and conveniences to } \\
\text { the community so that they } \\
\text { maintain relationships and } \\
\text { strengthen the bank's position in } \\
\text { the village (W1, T3). }\end{array}$
\end{tabular}

3. Similar banks were 3 . Forming leading village also established in the youth in socializing the sharia village. economy through the Basytama Institute and providing various facilities to facilitate activities (S2, S3, S4, T3).

\section{Basytama Implementation Development Strategy}

Based on the previous analysis, the right formula can be formulated in bridging Basytama to socialize sharia economy in the village, by preparing superior human resources in order to achieve improvement in sharia financial literacy in the village environment. Therefore, concrete steps are needed in implementing the ideas and results of the analysis above.

1. Development Master Plan

Making Basytama into the local government's development master plan in developing human resources is necessary, because apart from being a part of community development. The existence of Basytama is a part of implementing the Sustainable Development Goals (SDGs) so that it is expected to receive full support from the local government.

2. Socialization and Marketing

The process for the success of Basytama so that later the programs that are initiated will receive a positive response and are also known by the community, it is necessary to have active socialization and promotion in the community, either by installing billboards in front of the work office or playing an active role in contributing to village and neighbourhood activities/ hamlet.

3. Education

The importance of the process of educating the public in Islamic economics, especially improving the community's Islamic financial literacy, is the duty and responsibility of preachers and academics. Therefore, the direction of Basytama's movement is not only to increase sharia financial inclusion, but also to go directly to various village lines 
by entering the education curriculum.

4. Cooperation and Regeneration

The educational process and various socialization steps are deemed to be less than optimal if they do not revive the sharia economy from within the community itself. With this strategy, Basytama continues to optimize education and assistance programs through the Basytama Institute and Research Center so that it will give birth to agents of change from the community itself. In order to give birth to the successors and spreaders of the sharia economy itself, Basytama builds relationships with youth institutions in the village such as Islamic boarding schools, youth mosques, and organizations to make it easier to socialize and educate sharia economics. The following is an overview of the Basytama implementation development strategy.

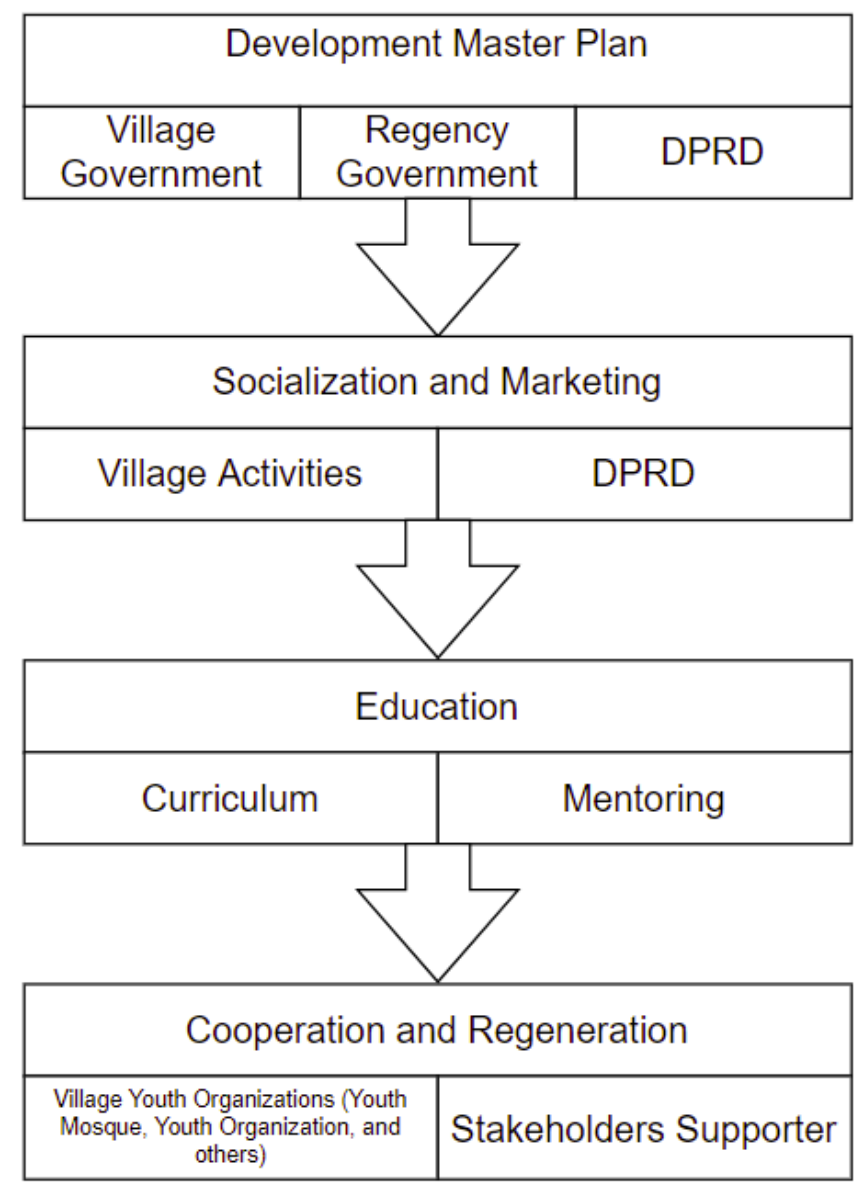

Chart 1 Basytama Implementation Development Strategy

\section{Conclusion}

Based on the results of the investigation through the distribution of questionnaires and interviews as well as alternative solutions, several points were obtained as follows:

1. Public knowledge, especially regarding Islamic financial literacy, which has an impact on Islamic banking information is still quite low and socialization is needed is shown in the results of our data acquisition when surveying the community online, where as many as $24.1 \%$ of village youth do not know about Islamic financial information.

2. Based on the situation experienced by the community through a survey we conducted and found that as many as $27.6 \%$ of the public do not know the concept of Islamic finance, then with Basytama can be a step in solving the problem. Basytama's role is to become an Islamic bank that aims to introduce Islamic financial products through village development, so that it is designed programs that maintain the function of the 
bank, but accompanied by programs that embrace the village.

3. The data we obtained through the survey found that in the application of Islamic finance to the family or nearby environment there are still $27.6 \%$ who have not implemented it, therefore efforts to improve Islamic financial literacy in villages, through Basytama which focuses on optimizing the role of youth in the village so that later become agents of change at least in their homes.

\section{Suggestion}

As a step in resolving and improving the condition of the community's Islamic financial literacy, collaboration with the central government is needed in this case with the financial services authority which can later be distributed to other Islamic financial institutions, both banks and non-banks. Excellence can be more comprehensive and more competitive. In line with this, it is also necessary to receive education from DSN MUI, especially in halal product certification, which is often an obstacle for rural communities to expand their business area, due to lack of knowledge and facilities being sought.

\section{References}

[1]Amdar, Sudarmin; Ventje llat; Agus Tony Poputra. 2016. "PENGARUH JUMLAH PENDUDUK MUSLIM, PEMBIAYAAN, DAN BAGI HASIL TERHADAP JUMLAH NOMINAL TABUNGAN NASABAH PADA BANK SYARIAH DI INDONESIA."

[2]Bank Indonesia. 2021. "Indeks Literasi Ekonomi Syariah." 2021.

[3]Bungin, Burhan. 2001. Metodologi Penelitian Kualitatif. Jakarta: Raja Grafindo Persada.

[4]CNN Indonesia. 2021. "180 Juta Umat Muslim, Baru 30 Juta Jadi Nasabah Bank Syariah." CNN Indonesia, 2021.

[5]David, Fred R. 201 1. "Analisis Dan Pilihan Strategi." In Manajemen Strategis Konsep, 12th ed., 326-31. Jakarta: Salemba Empat.

[6]Dayyan, Muhammad; Fariansah; Juprianto. 2017. "ANALISIS MINAT MASYARAKAT MUSLIM MENJADI NASABAH BANK SYARIAH (STUDI KASUS DI GAMPONG PONDOK KEMUNING)." Jurnal IImiah Mahasiswa 1 (1): 1-19.

[7]Dinar Standard. 2020. "State of The Global Economic Report."

[8] Gunawan, Imam. 2013. Metode Penelitian Kualitatif. Bumi Aksara.

[9]Hartomo, Giri. 2021. "Kedua Terbesar Di Dunia, Ini Kekuatan Indonesia Di Industri Keuangan Syariah." IDX Channel. 2021.

[10]Indi, Irnawati. 2019. "Faktor-Faktor Yang Memengaruhi Minat Masyarakat Menabung Di Bank Syariah (Studi Kasus Pada Masyarakat Di Kecamatan Rappocini Kota Makassar)." 2019.

[11]lzzati, Arini Nur. 2018. "Analisis Faktor-Faktor Yang Mempengaruhi Minat Mahasiswa Menabung Pada Bank Syariah." 2018.

[12]Kasmir. 2010. Dasar-Dasar Perbankan. Jakarta: PT. Raja Grafindo Persada.

[13]Nurrahman, Aldiansyah. 2019. "IFDI: Peringkat Industri Keuangan Syariah Indonesia Meroket Ke Peringkat Empat." KNEKS. 2019.

[14]Oktafia, R.; Ulfatul, K. 2012. "Pemberdayaan Masyarakat Pedesaan Dalam Keuangan Syariah." 2012. 
[15]Otoritas Jasa Keuangan. 2008. Undang-Undang Nomor 21 Tahun 2008 Tentang Perbankan Syariah. https://jdih.kemenkeu.go.id/fullText/2008/21TAHUN2008UU.htm.

[16]Rae, Dian Ediana. 2008. "Arah Perkembangan Hukum Perbankan Syariah." Buletin Hukum Perbankan Dan Kebanksentralan 6 (1): 1-7.

[17]Siddiqi, Muhammad Nejatullah. 1996. Islamic Banking System. Islamabad: Research Associates Press.

[18]Sukanto. 1985. Nafsiologi: Suatu Pendekatan Alternatif Atas Psikologi. Jakarta: Integrita Press. 